\title{
Analisis Citra Kuning Telur Berbasis Ekstraksi Ciri Statistika Orde Satu untuk Mengenali Jenis Telur Ayam Ras dan Ayam Kampung
}

\author{
Muhammad Sipan ${ }^{1)}$, dan Rony Kartika Pramuyanti ${ }^{2)}$ \\ 1,2,) Jurusan Teknik Elektro, Fakultas Teknik Universitas Semarang \\ 1,2) Jl. Soekarno-Hatta Tlogosari, Semarang 59160, Indonesia
}

\begin{abstract}
Chicken eggs are one of the most familiar side dishes in Indonesia besides tempeh. High protein and low prices make eggs a favorite side dish for the people of Indonesia. Although almost every day we see egg yolks we often can't tell for sure what chicken egg yolks we see. Based on this, the author tries to study egg yolk imagery based on first-order feature extraction using various features such as variance, skewness, carding, entropy, and mean. Statistical calculations are used based on the pixel values of the original image in this first-order texture calculation with the sole purpose of finding the histogram properties of the image. The results of first-order statistical characteristic calculations were used to differentiate between native and purebred chicken eggs. This study facilitates decision making, especially in the selection of accurate and measurable egg yolks from several types of chicken eggs, thereby minimizing public mistakes in choosing eggs based on egg yolks. The first step that can be done is to determine the data consisting of various types of images of free-range chicken egg yolks. These are freerange chicken eggs and purebred chicken eggs. The image is then segmented by separating the yolk and white, then first-order statistical analysis which later the results of these statistical calculations can be used as a reference in determining the type of egg. The results of the trial resulted in first-order feature extraction statistical values, namely for native chickens, the mean value was 132.743, min 69.5255, max 252.5, standard deviation was 29.922 and variance was 905.882 . The average value of statistics was order 1 for native chickens. of mean 137,176, min 48, max 240.2, standard deviation 31,454 and variance of 957.89.
\end{abstract}

Keywords: Egg yolk, order 1, extraction, segmentation

\begin{abstract}
ABSTRAK
Telur ayam adalah salah satu lauk pauk yang familiar di Indonesia selain tempe. Protein yang yang tinggi dan harga yang murah menjadikan telur menjadi lauk favorit bagi masyarakat Indonesia. Walapun hampir setiap hari kita melihat kuning telur kita sering tidak bisa membedakan secara pasti kuning telur ayam apa yang kita lihat. Berdasarkan hal ini, Penulis berusaha untuk mengkaji citra kuning telur berbasis ekstraksi ciri secara orde satu menggunakan berbagai fitur seperti varians, skewness, carding, entropy, dan mean. Digunakan perhitungan statistik berdasarkan nilai piksel dari citra asli pada perhitungan tekstur orde satu ini dengan tujuan tunggal untuk menemukan sifat histogram dari gambar. Hasil perhitungan karakteristik statistik orde satu digunakan untuk membedakan antara jenis telur ayam kampung dan ayam ras. Penelitian ini memudahkan dalam pengambilan keputusan khususnya dalam pemilihan kuning telur yang akurat dan terukur dari beberapa jenis telur ayam, sehingga meminimalisir kesalahan masyarakat dalam memilih telur berdasarkan kuning telur. Langkah pertama yang dapat dilakukan adalah menentukan data yang terdiri berbagai jenis citra kuning telur ayam kampung. Ini adalah telur ayam kampung dan telur ayam ras. Citra tersebut kemudian disegmentasi dengan memisahkan kuning dan putihnya, kemudian analisis statistik orde pertama yang nantinya hasil perhitungan statistik tersebut dapat dijadikan acuan dalam menentukan jenis telur. Hasil uji coba dihasilkan nilai nilai statistika ektraksi ciri orde satu yaitu untuk untuk ayam kampung nilai rata-rata mean sebesar 132.743, min 69.5255, $\max 252.5$, standar deviasi 29.992 dan variance sebesar 905. 882. Nilai rata-rata statistika orde 1 untuk ayam kampung sebesar mean 137.176, $\min 48$, max 240.2, standar deviasi 31.454 dan variance sebesar 957.89.
\end{abstract}

Kata kunci: Kuning Telur, orde 1, ekstraksi, segmentasi

\section{Pendahuluan}

$\mathrm{T}$ Telur merupakan sebuah makanan yang mengandung protein tinggi, dalam kehidupan sehari-hari orang akan dapat menentukan jenis telur ayam berdasarkan apa yang dilihat, misalkan bentuk, besar dan warna dari telur tersebut. Tetapi berbeda apa bila kita melihat kuning telur dari beberapa jenis ayam. Kita akan mengalami kesulitan dikarenakan warna dan bentuk yang hampir sama, dari permasalahan tersebut seseorang akan mengalami kesulitan dalam menentukan jenis telur secara terukur.

Berdasarkan permasalahan tersebut Peneliti mengkaji bagaimana mengidentifikasi jenis telur ayam dengan ekstraksi ciri secara statistik orde satu untuk mencari seberapa nilai karateristik histogram citra kuning telur seperti nilai variance, skewness, kartulasi, entropi dan nilai mean untuk menunjukan jenis telur ayam.

\section{A. Analisa tekstur}

Umumnya analisis tekstur digunakan dalam bermacam-macam aplikasi untuk menyelesaikan masalah guna mencapai tujuan tertentu. Misalkan Untuk identifikasi, [2] [3] klasifikasi [4 [5], analisis pencitraan medis [6] dan aplikasi lainnya. Menurut Bharati [3], beberapa pendekatan yang biasa digunakan pada analisis tekstur adalah statistik, struktural, berbasis model, dan berbasis transformasi. Salah satu metode statistik adalah 
ekstraksi ciri orde satu pada eksperimen studi ekstraksi ciri yang digunakan penelitian ini.

\section{B. Ekstraksi Ciri Statistik}

Ekstraksi fitur statistik terdiri dari ekstraksi fitur statistik orde pertama dan ekstraksi fitur statistik orde dua. Ekstraksi fitur orde satu didapatkan dengan menggunakan histogram citra. Ekstraksi fitur statistik orde dua diperoleh dengan menggunakan matriks cooccurrence. Matriks co-occurrence adalah matriks perantara yang mewakili kedekatan antara piksel pada suatu citra dalam berbagai arah dan jarak spasial yang berbeda.

Metode ekstraksi ciri statistik yang digunakan adalah untuk perhitungan statistik distribusi tingkat keabuan (histogram) dengan menentukan nilai tingkat kekontrasan, kekasaran piksel, dan kekasaran permukaan piksel yang berdekatan pada citra.

Gambar 1 menunjukkan histogram citra di sebelah kiri sebagai fungsi peluang terjadinya nilai intensitas pada citra. Di sebelah kanan adalah adjacency antara piksel sebagai fungsi arah dan jarak spasial, dari $0^{\circ}$ hingga $135^{\circ}$. Kiri atas adalah jarak yang berdekatan dengan sudut $0^{\circ}$, kanan atas adalah sudut $45^{\circ}$, kiri bawah adalah jarak spasial dengan sudut $90^{\circ}$, dan kiri bawah adalah sudut 135 .
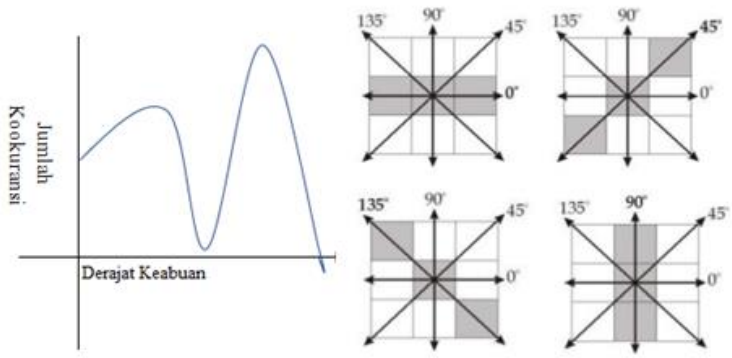

Gambar 1. Ilustrasi ekstraksi fitur statistik

\section{Ekstraksi Ciri Orde Pertama}

Ekstraksi fitur primer adalah metode pengamatan fitur berdasarkan karakteristik histogram dari suatu citra. Histogram menunjukkan kemungkinan munculnya nilai tingkat keabuan untuk suatu piksel pada citra. Dari nilai dalam histogram yang dihasilkan, Anda dapat menghitung beberapa parameter linier karakteristik seperti mean, skewness, variance, kurtosis, dan entropy. a. Mean $(\mu)$ Membahas ukuran dispersi dari suatu citra.

$$
\mu=\sum_{n} f n P(f n)
$$

Dengan $f n$ adalah nilai intensitas keabuan dan $\mathrm{p}$ (fn) berarti nilai histogram (probabilitas intensitas yang akan muncul dari citra).

b. Vriance $\left(\sigma^{2}\right)$ Menjelaskan variasi elemen pada histogram dari suatu citra.

$$
\sigma^{2}=\sum_{n}(f n-\mu)^{2} P(f n)
$$

c. Skewness ( $\alpha 3)$ Menjelaskan tingkat kemencengan relatif kurva histogram suatu citra.

$$
\alpha 3=\frac{1}{\sigma^{2}} \sum_{n}(f n-\mu)^{2} P(f n)
$$

d. Kurtosis $(\alpha 4)$

Menjelaskan tingkat keruncingan relatif kurva histogram dari citra.

$$
\alpha 4=\frac{1}{\sigma^{4}} \sum_{n}(f n-\mu)^{4} P(f n)-3
$$

$e$. entropy $(\mathrm{H})$

Menjelaskan ketidakteraturan bentuk dari suatu citra $\mathrm{H}=-\sum_{n} P(f n)^{2} \cdot \log p(f n)$

\section{Metode Penelitian}

Penelitian ini menggunakan statistik orde satu pada ayam pedaging dan telur ayam kampung untuk mendeskripsikan analisis ekstraksi ciri dari kuning telur. Nilai statistik orde satu yang didapatkan, dipakai sebagai panduan penentuan citra kuning telur ayam kampung atau telur ayam kampung. Fitur utama yang dipakai meliputi mean, varians, skewness, kurtosis, dan entropy.

Penelitian ini digunakan untuk menentukan nilai karakteristik histogram dari masing-masing citra kuning telur tersebut. Dengan ciri statistik ini kita dapat menentukan kuning telur ayam apa yang kita lihat.

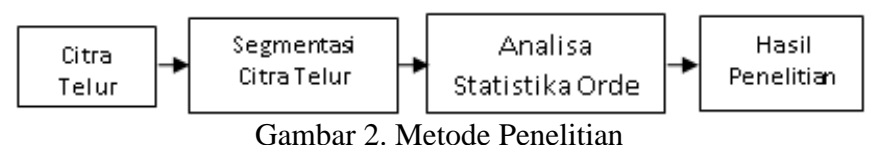

Gambar 2. Menunjukan langkah-langkah penelitian, yang pertama adalah citra telur yang akan kita cari nilai statistiknya, Citra kuning telur diambil dengan kamera Samsung A7 dengan isi telur kampung dan isi telur Ras masing-masing berisi 30 butir telur. Selanjutnya, kami menyegmentasikan 60 gambar kuning telur untuk memisahkan kuning dan putihnya dan menggunakan citra kuning telur.Pada langkah ketiga mencari nilai statisktik kuning telur yang digunakan, nilai statistic citra ini merupakan ciri dari citra kuning telur yang meliputi nilai mean, variance, skewness, entropi dan kurtosis, nilai dari citra tersebut.

Fitur ini merupakan karakteristik histogram citra kuning telur yang meliputi ukuran disperse dari citra, variasi elemen citra, tingkat kemencengan relatif histogram, tingkat keruncingan relative kurva citra, dan ketidakteraturan bentuk dari citra yang kita teliti. Setelah dihasilkan nilai-nilai tersebut selanjutnya di cari nilai-nilai errors untuk membedakan antara kuning telur ayam kampung dengan kuning telur ayam Ras dengan melihat nilai-nilai ekstraksi ciri yang ada.

\section{HASIL Dan Pembahasan}

Bagian ini menjelaskan temuan dan hasil pengujian yang dilakukan dengan menjalankan beberapa skenario. Hasil yang dibahas adalah hasil penelitian nilai fitur warna, nilai histogram, dan ekstraksi fitur tekstur. Setelah nilai diambil, nilai kesalahan dicari untuk 
mengambil citra yang paling mirip dengan gambar yang direferensikan. Nilai fungsional yang dihasilkan dijelaskan pada subbagian berikutnya.

\section{A. Data Penelitian}

Data yang diambil terdiri dari 20 citra dari citra kuning telur ayam kampung dan 10 citra kuning telur ayam kampung JPG. Gambar 3 menunjukkan citra kuning telur ayam kampung, dan Gambar 4 menjelaskan gambar kuning telur ayam kampung. Terlihat warna kuning telur ayam ras lebih muda dibandingkan kuning telur ayam kampung yang terlihat lebih kuning keoranyean.

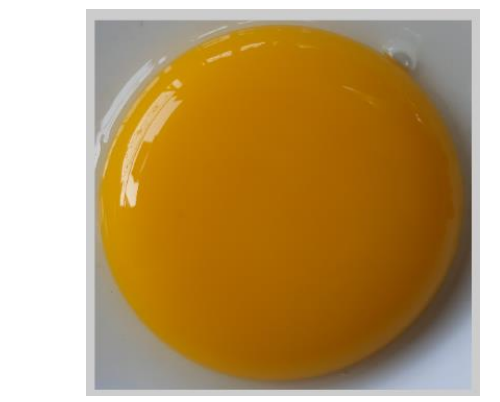

Gambar 3 . Data Kunng Telur Ayam Ras

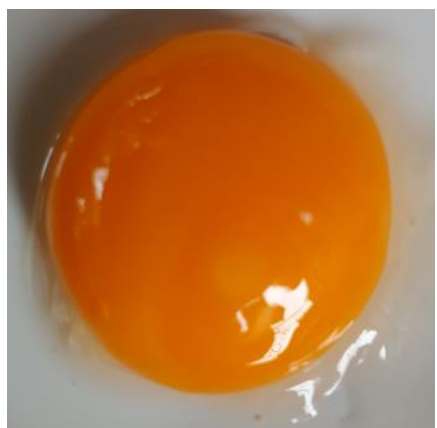

Gambar 4. Kuning Telur Ayam Kampung

\section{B. Proses Segmentasi}

Segmentasi adalah teknik untuk membagi suatu citra menjadi beberapa bagian, seperti bagian frontground atau background. Setiap bagian memiliki kemiripan atribut. Pada penelitian ini segmentasi digunakan untuk mengetahui citra biner, komplemen citra, operasi morfologi seperti filling holes, dan citra grayscale hasil segmentasi. Langkah-langkah tesebut terapat pada gambar 5 sampai gambar 9.

Proses pertama adalah citra asli kuning telur di rubah kedalam citra grayscale untuk mengetahui tektur atau intesnsitas citra kuning telur yang ditunjukkan pada gambar 5. dimana dijelasknan mana area atau daerah yang memiliki intensitas tinggi maupun rendah. Secara kasat mata intensitas tinggi ditunjukan dengan garis pada citra kuning dan instensitas rendah ditunjukan pada bagian bawah kanan citra kuning telur.

Gambar 6. Menjelaskan hasil dari proses thresholding berupa citra biner yang menunjukkan dua nilai tingkat keabuan yaitu hitam dan putih dimana pada penelitian ini dilakukan segmentasi global thresholding.

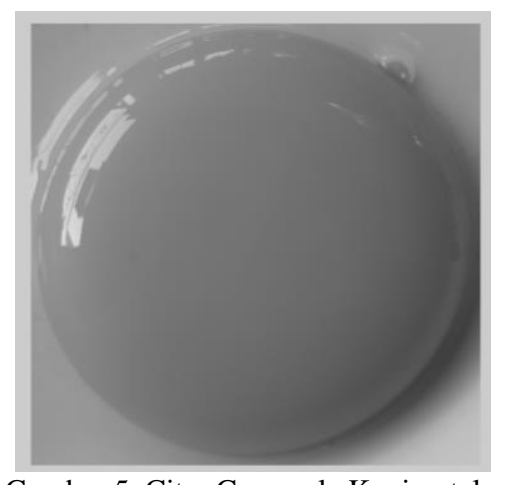

Gambar 5. Citra Grayscale Kuning telur

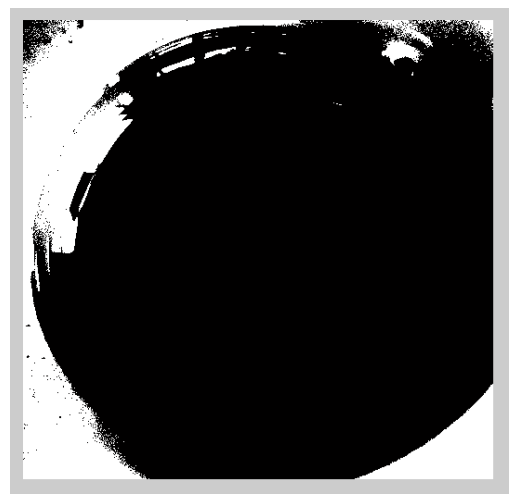

Gambar 6. Citra Biner dari Proses Thresholding Citra Grayscale

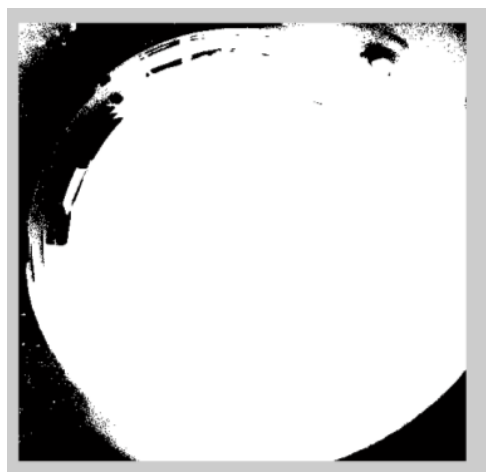

Gambar 7. Citra Komplemen

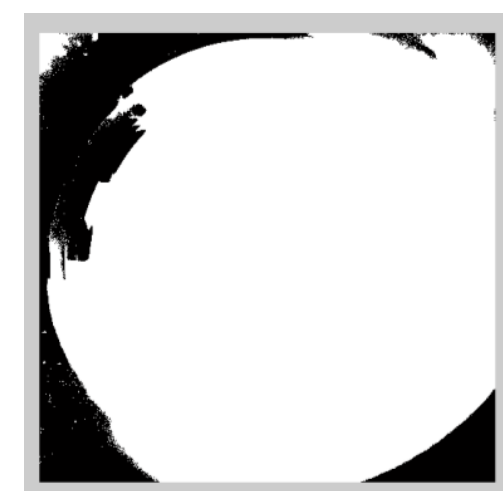

Gambar 8. Citra Morfologi berupa filling holes

Gambar 7 dan gambar 8 menunjukkan hasil proses komplemen citra dan morfologi citra. Komplemen citra agar objek kuning telur berwarna putih (1) dan background berwarna hitam (0). Morfologi citra digunakan untuk merubah citra asli dan mengetahui bentuk citra kuning telur berupa filling holes untuk memperbaiki citra grayscale atau citra biner. 


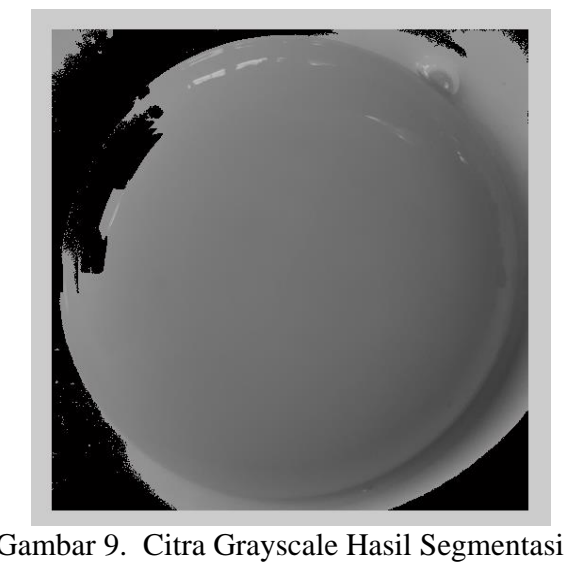

Setelah proses komplemen citra dan segmentasi morfologi citra dilanjukan proses grayscale hasil segmentasi yang dijelaskan pada gambar 9. Pada gambar ini dapat kita lihat kuning telur dalam skala keabuan dan background terlihat lebih gelap dibandingkan citra aslinya.

\section{Ekstraksi Ciri Oede 1}

Pengujian penelitian ini dgunakan statistik orde satu dengan fitur citra yang terdiri mean, minimum-max, standar deviasi, dan varians. Penentuan persentase titik yang ditunjukkan pada Gambar 10 mencakup lima titik dengan koordinat pada posisi berikutnya 2000.1400; 2000.1500; 2000.1600; 2000.1700; 2000.1800 piksel.

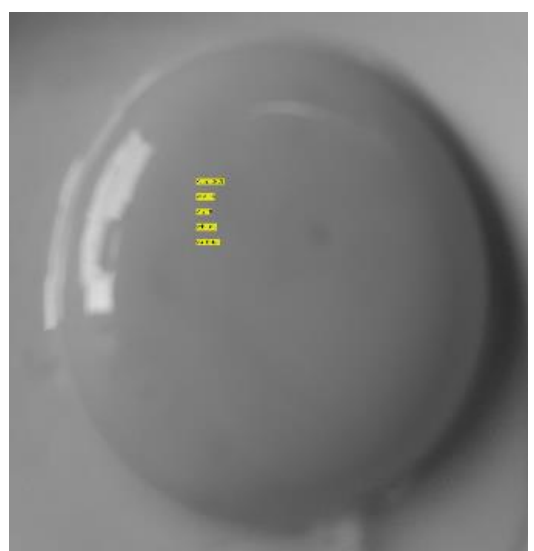

Gambar 10. Titik Koordinat Kelima Ciri Ekstraksi yang Digunakan

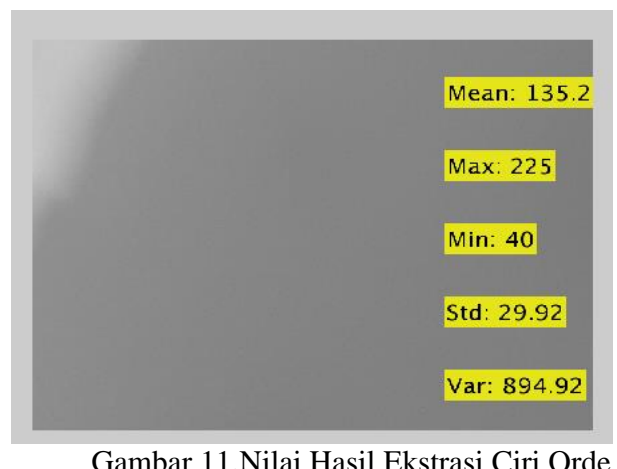

Gambar 11.Nilai Hasil Ekstrasi Ciri Orde
Gambar 11. Menjelaskan lima fitur yang digunakan pada Gambar 20 dijelaskan dengan rata-rata 135,2, minimum 40, dan maksimum 225. Standar deviasi adalah 29,92 dan varians adalah 894,92. Tabel 1 menunjukkan nilai total statistik ekstraksi sifat primer yang diperoleh dari survei. Ini menggambarkan nilai dari lima sifat yang digunakan dalam setiap gambar kuning telur.

Tabel 1. Nilai Statistik Ekstraksi ciri Orde 1

\begin{tabular}{|c|c|c|c|c|c|c|}
\hline Telur & Citra & M ean & Min & Max & Std & Var \\
\hline \multirow{10}{*}{$\begin{array}{c}\text { Ayam } \\
\text { Ras }\end{array}$} & 1 & 135.29 & 40 & 225 & 29.92 & 894.92 \\
\hline & 2 & 133.44 & 38 & & 29.79 & 887.59 \\
\hline & 3 & 135.35 & 56 & 244 & 30.53 & 932.32 \\
\hline & 4 & 130.97 & 57 & 240 & 28.55 & 815.11 \\
\hline & 5 & 130.47 & 29 & 236 & 24.51 & 600.8 \\
\hline & 6 & 131.86 & 60 & 236 & 25.24 & 636.87 \\
\hline & 7 & 152.61 & 52 & 249 & 40.38 & 1630.28 \\
\hline & 8 & 153.17 & 47 & 251 & 38.98 & $1519-42$ \\
\hline & 9 & 136.09 & 51 & 248 & 34.39 & 1182.85 \\
\hline & 10 & 132.51 & 50 & 246 & 32.25 & 1040.27 \\
\hline \multirow{10}{*}{$\begin{array}{c}\text { Ayam } \\
\text { Kamp ung }\end{array}$} & 11 & 138.26 & 78 & 255 & 34.81 & 1211.85 \\
\hline & 12 & 137.93 & 82 & 255 & 30.08 & 904.92 \\
\hline & 13 & 140.94 & 92 & 252 & 26.1 & 681.09 \\
\hline & 14 & 126.37 & 79 & 255 & 29.44 & 866.45 \\
\hline & 15 & 126.33 & 73 & 255 & 32.28 & 1041.87 \\
\hline & 16 & 125.4 & 78.255 & 255 & 28.86 & 833 \\
\hline & 17 & 140.34 & 51 & 255 & 32.26 & 1040.89 \\
\hline & 18 & 133.91 & 50 & 249 & 30.78 & 947.17 \\
\hline & 19 & 136.83 & 55 & 254 & 28.69 & 822.9 \\
\hline & 20 & 121.12 & 57 & 240 & 26.62 & 708.68 \\
\hline
\end{tabular}

Nilai terbesar dari masing-masing ciri adalah: Nilai mean adalah 153,17 . Artinya, pada citra kuning telur ke8 didapatkan nilai maksimal dan minimal dari citra kuning telur ke-13. Itu adalah 92. Nilai maksimum ada di beberapa gambar, tanggal 11, 12, dan 14, 15. Foto 16 , 17.66 foto kuning telur ayam. Standar deviasi maksimum terdapat pada citra kuning telur ke-7 yaitu citra kuning telur ayam ras, dan varians maksimal pada citra ke-7 sebesar 1630,27.

\section{Penutup}

\section{A. Kesimpulan}

Setelah dilakukan beberapa uji coba dihasilkan nilai nilai statistika ektraksi ciri orde 1 yaitu untuk untuk ayam kampung nilai rata-rata mean sebesar 132.743 , min 69.5255, $\max 252.5$, standar deviasi 29.992 dan variance sebesar 905.882 . Nilai rata-rata statistika orde 1 untuk ayam kampung sebesar mean 137.176, min 48, $\max 240.2$, standar deviasi 31.454 dan variance sebesar 957.89 .

Nilai-nilai tersebut menunjukkan ayam ras memiliki nilai mean, standar deviasi dan varian yang lebih besar dari ayam kampung ini berarti ukuran dispersi citra, sebaran nilai intensitas citra dan seberapa dekat setiap nilai intensitas citra dengan garis nilai intensitas ratarata citra dan variasi elemen pada histogram ayam ras lebih besar dari ayam kampung, tetapi untuk nilai min dan max ayam kampung lebih besar dari ayam ras yaitu 
sebesar 69.5255 dan 252.5 yang berarti nilai paling tinggi dan paling rendah pada citra kuning telur.

\section{B. Saran}

Berdasarkan Hasil penelitian yang dilakukan dan kesimpulan yang di ambil penulis memiliki saran yang dapat diambil oleh peneliti selanjutnya seperti fitur ekstraksi ciri untuk lebih tepat menentukan kuning telur ayam kampung atau ayam ras untuk dapat berkembang biak. Selain itu, jumlah data dalam dua gambar dapat ditambahkan dan titik fitur lebih lanjut dapat ditentukan untuk memungkinkan fitur yang lebih beragam dihasilkan.

\section{DAFTAR PUStaka}

[1] Ahmad Muzami1), Oky Dwi Nurhayati2), Kurniawan Teguh Martono2) Aplikasi Identifikasi Citra Telur Ayam Omega-3 Dengan Metode Segmentasi Region Of Interest Berbasis Android. Jurnal Teknologi dan Sistem Komputer, Vol.4, No.2, April 2016 (e-ISSN: 2338-0403)

[2] Sipan Muhammad, Kartika Roni P. Analisis Tekstur Photo Lama Menggunakan Fitur Tekstur Gray Level Co-Occurrence Matriks Pada Pewarnaan Citra Otomatis' Semarang, 2017

[3] Ustin Sousa, Rasoul Kabirzadeh, Patrick Blaes, "Automatic Colorization of Grayscale Images", Department of Electrical Engineering, Stanford University, 2013.

[4] Susanto adi, Kadir abdul, Teori dan aplikasi pengolahan citra,Penerbit andi, Yogyakarta. 2012

[5] Rahayu, I. H. (2003). Karakteristik Fisik, Komposisi Kimia dan Uji Organoleptik Telur Ayam Merawang Dengan Pemberian Pakan Bersuplemen Omega-3. Jurnal Teknologi dan Industri Pangan, Vol. XIV. 